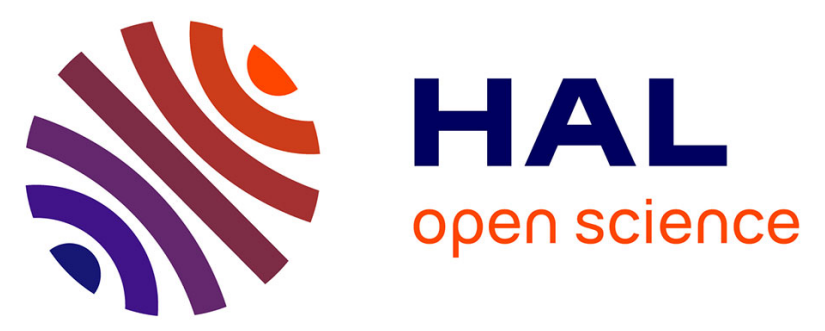

\title{
Dynamics of nitrate and nitrite content during storage of homemade and small-scale industrially produced raw vegetable juices and their dietary intake.
}

Terje Tamme, Mari Reinik, Tõnu Püssa, Mati Roasto, Kadrin Meremäe, Alida Kiis

\section{To cite this version:}

Terje Tamme, Mari Reinik, Tõnu Püssa, Mati Roasto, Kadrin Meremäe, et al.. Dynamics of nitrate and nitrite content during storage of homemade and small-scale industrially produced raw vegetable juices and their dietary intake.. Food Additives and Contaminants, 2010, 27 (04), pp.487-495. 10.1080/19440040903439796 . hal-00576980

\section{HAL Id: hal-00576980 https://hal.science/hal-00576980}

Submitted on 16 Mar 2011

HAL is a multi-disciplinary open access archive for the deposit and dissemination of scientific research documents, whether they are published or not. The documents may come from teaching and research institutions in France or abroad, or from public or private research centers.
L'archive ouverte pluridisciplinaire HAL, est destinée au dépôt et à la diffusion de documents scientifiques de niveau recherche, publiés ou non, émanant des établissements d'enseignement et de recherche français ou étrangers, des laboratoires publics ou privés. 


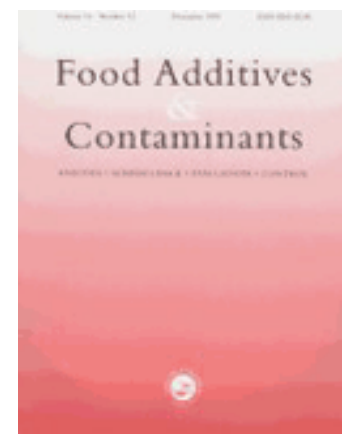

\section{Dynamics of nitrate and nitrite content during storage of homemade and small-scale industrially produced raw vegetable juices and their dietary intake.}

\begin{tabular}{|c|c|}
\hline Journal: & Food Additives and Contaminants \\
\hline Manuscript ID: & TFAC-2009-208.R1 \\
\hline Manuscript Type: & Original Research Paper \\
\hline $\begin{array}{r}\text { Date Submitted by the } \\
\text { Author: }\end{array}$ & 14-Oct-2009 \\
\hline Complete List of Authors: & $\begin{array}{l}\text { Tamme, Terje; Estonian University of Life Sciences, Department of } \\
\text { Food Science and Hygiene, Institute of Veterinary Medicine and } \\
\text { Animal Sciences } \\
\text { Reinik, Mari; Estonian Health Protection Inspectorate, Tartu } \\
\text { Laboratory } \\
\text { Püssa, Tõnu; Estonian University of Life Sciences, Department of } \\
\text { Food Science and Hygiene, Institute of Veterinary Medicine and } \\
\text { Animal Sciences } \\
\text { Roasto, Mati; Estonian University of Life Sciences, Department of } \\
\text { Food Science and Hygiene, Institute of Veterinary Medicine and } \\
\text { Animal Sciences } \\
\text { Meremäe, Kadrin; Estonian University of Life Sciences, Department } \\
\text { of Food Science and Hygiene, Institute of Veterinary Medicine and } \\
\text { Animal Sciences } \\
\text { Kiis, Alida; Estonian University of Life Sciences, Department of Food } \\
\text { Science and Hygiene, Institute of Veterinary Medicine and Animal } \\
\text { Sciences }\end{array}$ \\
\hline Methods/Techniques: & Chromatographic analysis, Health significance, Microbiology \\
\hline Additives/Contaminants: & Nitrate, Nitrite \\
\hline Food Types: & Beverages, Vegetables \\
\hline
\end{tabular}


Note: The following files were submitted by the author for peer review, but cannot be converted to PDF. You must view these files (e.g. movies) online.

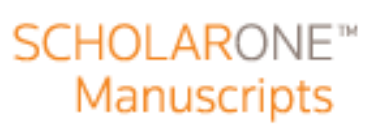

13

14

15

16

17

18

19

20

21

22

23

24

25

26

27

28

29

30

31

32

33

34

35

36

37

38

39

40

41

42

43

44

45

46

47

48

49

50

51

52

53

54

55

56

57

58

59

60

http://mc.manuscriptcentral.com/tfac Email: fac@tandf.co.uk 
Dynamics of nitrate and nitrite content during storage of homemade and small-scale industrially produced raw vegetable juices and their dietary intake

\author{
T. TAMME ${ }^{\mathbf{a}^{*}}$, M. REINIK ${ }^{\mathrm{b}}$, T. PÜSSA ${ }^{\mathrm{a}}$, M. ROASTO $^{\mathrm{a}}, \mathrm{K}_{\text {REREMÄE }}{ }^{\mathrm{a}}$, A. KIIS $^{\mathrm{a}}$
}

${ }^{a}$ Department of Food Science and Hygiene, of Estonian University of Life Sciences, Kreutzwaldi 58A, 51014 Tartu, Estonia

${ }^{\mathrm{b}}$ Estonian Health Protection Inspectorate, Tartu Laboratory, PK 272, 50002 Tartu, Estonia

* Correspondending author: E-mail: terje.tamme@emu.ee 


\begin{abstract}
The influence of storage conditions on nitrate and nitrite contents, $\mathrm{pH}$ and total viable bacterial count of raw vegetable juices was studied. Three different types of juices from an Estonian small-scale producer and five different types of homemade juices were analyzed. Analyzes were performed immediately after opening the commercial juice packages and immediately after preparation of a homemade juice. Additionally, samples were taken after open storage of a juice at the refrigerator and ambient temperatures during 24 and 48 hours. The biggest changes in nitrate and nitrite contents were found during the storage of carrot, beetroot and radish juices. During 48 hours of storage at ambient temperature the mean increase of nitrite content in homemade carrot, beetroot and radish juices were from 0.1 to 187, from 2.1 to 578 and from 0.5 to 259 , respectively. In the case of commercial lightly pasteurized products, the biggest increase of nitrite content, from 3.2 to $11 \mathrm{mg} \mathrm{l}^{-1}$ was found in red beetroot juice. After $48 \mathrm{~h}$ of storage at refrigerator temperature the changes of nitrite and nitrate were smaller. In the case of consumption of $300 \mathrm{ml}$ homemade carrot juice, with nitrate and nitrite content of 64 and $110 \mathrm{mg} \mathrm{l}^{-1}$, respectively, stored for $24 \mathrm{~h}$ at ambient temperature, the average intake is 8 and $846 \%$ of ADI of nitrates and nitrites, respectively. After consumption of $50 \mathrm{ml}$ of the same carrot juice by children (1-2 years) the average intake of nitrates and nitrites is $7.0 \%$ and $733 \%$ of ADI, respectively.
\end{abstract}

Keywords: raw vegetable juice, nitrate, nitrite, storage, intake, ADI

\title{
Introduction
}

Interest in the dietary intakes of nitrates and nitrites has arisen due to the concern about their possible adverse effect on health (Belitz et al. 2004; Thomson et al. 2007, EFSA, 2008).

Nitrate has a low level of acute toxicity but may be transformed into nitrite, which may lead to the formation of carcinogenic nitrosoamines (Walker, 1990, Kolb et al. 1997) and the clinical symptoms of methaemoglobinemia (WHO, 1995; Sanchez-Echaniz et al. 2001; Santamaria, 2006). Infant methemoglobinemia has been shown to be a result of consumption of high doses of nitrates by the infant foods and drinking water (Ezeagu, 1996, Coss et al. 
2003, Thomson et al. 2007). The acceptable daily intake (ADI) for nitrate is from 0 to 3.7 $\mathrm{mg} / \mathrm{kg}$ body weight, and for nitrite from 0 to $0.06 \mathrm{mg} / \mathrm{kg}$ body weight, established by EU Scientific Committee for Food (EU Scientific Committee, 1995) and reconfirmed by JECFA in 2002.

Vegetable juices are an important source of essential nutrients for humans. During the last years the vegetable-based raw juices have become very popular. The popularity has arisen due to public interest in variable diets and alternative nutrition. Nitrate is naturally present in all vegetables and vegetable products that are substantial sources of nitrates in human intake. Some vegetables, such as carrot, pumpkin and cabbage, and particularly red beetroot and radish, can accumulate high levels of nitrates. Consumption of $150 \mathrm{ml}$ of red beetroot juice containing $2000 \mathrm{mg}^{-1}$ nitrate thus would already result an intake greater than ADI value for a $70 \mathrm{~kg}$ adult (Kolb et al. 1997).

Nitrite content of most fresh, frozen or canned vegetables is generally low and usually in the range of 0 to $2 \mathrm{mg} / \mathrm{kg}$ (Meah et al. 1994, Pennington 1998, Chung et al. 2003, Belitz et al. 2004, Hsu et al. 2009). Reduction of nitrate to nitrite may take place in the presence of bacteria or enzyme nitrate reductase (Phillips, 1968, Chung et al. 2004) and after improper storage, especially of homemade vegetable products like purees and juices (Heisler et al. 1974; Kolb et al. 1997, Shanchez-Echaniz et al. 2001). It has been estimated that from 5 to $8 \%$ of the nitrate from the diet may be reduced to nitrite by the microflora in the oral cavity (Mensinga et al. 2003) and up to $20 \%$ for individuals with a high rate of conversion (WHO 1995).

If food contains high levels of nitrate, it is a potential risk if the conditions during storage or processing are conductive to conversion to nitrite (Hill 1996, EFSA, 2008). Most critical are vegetables that have been damaged, poorly stored, or stored for extended periods, pickled and fermented vegetables as well as raw vegetables juices. In such circumstances, nitrite levels of up to $400 \mathrm{mg} \mathrm{kg}^{-1}$ have been found (WHO, 1995). In fermented maize on storage in water at room temperature over period of 8 days, nitrate levels decreased $80 \%$ in average while the nitrite content increased about 200\% in average of its initial level (Ezeagu, 1996).

There is very limited up-to-date scientific information available on nitrate and nitrite levels and dynamics in the raw vegetable juices. According to the results of the earlier studies (Phillips, 1968, Heisler et al. 1974) the initial nitrate present in fresh vegetable juices was significantly reduced to nitrite under storage at ambient temperature. In 1994 Nabrzyski and Gajewska reported the decrease of nitrate from 261 to $46 \mathrm{mg} \mathrm{kg}^{-1}$ with consequent increase of 
nitrite from 0.14 to $83.0 \mathrm{mg} \mathrm{kg}^{-1}$ for juices prepared from blanched carrot and stored at ambient temperatures.

During storage of homogenized leafy vegetables (spinach, crown daisy, etc.) at ambient temperature, nitrate levels in the vegetables dropped significantly (mean 87.4\%) from the third day while nitrite levels increased dramatically in the range of 1857 to $3617 \mathrm{mg} \mathrm{kg}^{-1}$. Refrigerated storage did not lead to significant changes in nitrate and nitrite levels in the homogenized leafy vegetables (Chung et al. 2004). Phillips (1968) reported that after storage of fresh homogenized spinach at ambient temperatures nitrate content was reduced to approximately $64 \%$ of its initial level.

Considerable public interest has lately been focused on the consumption of raw vegetable juices (Yabsley and Cross, 2001; Kroom, 2008). Different methods, like food supply data, published tables of the mean consumption of dietary items, duplicate portion analysis, dietary survey among the individuals, probabilistic and worse case screening models are used for estimation of the nitrate and nitrite intake from food and for calculations of the acceptable daily intakes (Ellen et al. 1990; Penttilä et al. 1990; Murata et al. 2002). Depending on the method used, intake estimates can vary to a large extent (Kroes et al. 2002).

According to the Scientific Opinion of the Panel on Contaminants in the Food Chain of the European Food Safety Authority, adopted on 10 April 2008, there is a need for further research into the factors that influence nitrate and nitrite concentrations and alterations during production, storage and processing of the foodstuffs (EFSA, 2008).

The aim of the present work was to study the changes of nitrate and nitrite levels in selected raw vegetables juices under refrigerated and ambient temperature storage conditions for a period of 2 days. The assessment of dietary nitrate and nitrite intake by consumption of raw vegetable juices in accordance with acceptable daily intakes (ADI) was the second objective of the present work.

\section{Materials and methods}

\section{Juices}

All juices were analysed in five replications.

Series 1 analyses were performed with lightly pasteurizated raw juices of carrot, cabbage and red beetroot, produced at a small-scale local enterprise and purchased at retail market. Light pasteurization is directed at vegetative microorganisms and is usually conducted at about $65^{\circ} \mathrm{C}$ during 10 seconds (Sadler et al., 1992). The series 2 consisted of homemade raw juices 
prepared in the laboratory following the traditional raw juice preparation at homes without any pasteurization. Briefly, samples of five species of vegetables, i.e. carrot, cabbage, red beetroot, radish and pumpkin were collected from different outlets of Tartu, Estonia. The vegetables were washed with warm water, mechanically brushed and peeled. Raw juices were produced with commercially available squeezer (Stollar Juice Fountain).

All the raw juices were stored at two different temperatures, refrigerated $\left(4-6{ }^{\circ} \mathrm{C}\right)$ and ambient $\left(20-22^{\circ} \mathrm{C}\right)$ for two days. The nitrate and nitrite contents, total viable counts, coliforms counts, yeast and moulds counts and $\mathrm{pH}$ were determined after opening the commercial juice packages and immediately after preparation of the homemade juices as well as after 24 and 48 hours of storage.

\section{HPLC analysis of nitrate and nitrite ions}

HPLC analyses were performed by a liquid chromatograph (Agilent Technologies Model 1100, Palo Alto, CA, USA) equipped with a fluorescence detector. Chromatographic separation of samples and standards was carried out at a reversed phase column Agilent $300 \mathrm{SB}_{-} \mathrm{C}_{8}(2,1 \times 150 \mathrm{~mm}, 5 \mu \mathrm{m}$; Agilent Technologies, USA) using gradient elution with $0.1 \%$ formic acid and acetonitrile eluent at $35^{\circ} \mathrm{C}$ with a speed of $0.2 \mathrm{ml} / \mathrm{min}$. Fluorescence was monitored with excitation at $355 \mathrm{~nm}$ and emission at $420 \mathrm{~nm}$.

Nitrate ions were converted to nitrite enzymatically by nitrate reductase and further to the highly fluorescent 2.3-naphthotriazole (NAT) with 2.3-diaminonaphthalene (DAN) as described in literature (Misko et al. 1993; Li et al. 2000). Obtained solution was used directly for chromatographic analysis. Conversion rate of nitrate to nitrite was $98 \%$, as detected with known amounts of nitrate and nitrite standards. All chemicals were purchased from Sigma, except sodium nitrate and potassium nitrite which were obtained from Riedel-de Haën. Limit of quantification (LOQ) of nitrate was $0.23 \mathrm{mg} \mathrm{l}^{-1}$ and of nitrite $0.10 \mathrm{mg} \mathrm{l}^{-1}$.

\section{Bacteriological analyses}

All juices were examined microbiologically for total viable counts, coliform bacteria, yeasts and moulds using the four plate method. Decimal dilution series were prepared in accordance with EVS-EN ISO 6887-1:2001. Plate Count Agar LAB 115 was used for isolation of total viable counts at $30^{\circ} \mathrm{C}$ for $72 \mathrm{~h}$ (EVS-EN ISO 4833:2006). Coliforms were grown in the Violet Red Bile Agar LAB 31 (V.R.B.A.) at $37^{\circ} \mathrm{C}$ for $24 \mathrm{~h}$ (NMKL 44 5th edition 2001). Yeast extract-dextrose-chloramphenicol-agar medium LAB 119-B5 was used for isolation of 


\section{Statistical analysis}

All individual laboratory results of nitrate and nitrite content were recorded and the statistical analyses were performed using MS Excel 2003 software (Microsoft Corporation; Redmond, WA, USA) T-test was used to reveal the statistical significance of differences in measured variables at different time points. The results with values $\mathrm{p}<0.05$ were considered statistically significant. Correlation analyses were used to study relationships between the $\mathrm{pH}$ and total viable count of aerobic bacteria $(\log \mathrm{cfu} / \mathrm{ml})$ as well as between nitrate/nitrite content and total viable count of bacteria $(\log \mathrm{cfu} / \mathrm{ml})$.

\section{Results and discussion}

The range and mean values of initial nitrate and nitrite contents in the studied vegetable-based juices are shown in Table 1. The highest mean initial values of nitrate were obtained for the homemade juices of beetroot and radish, 2625 and $4615 \mathrm{mg} \mathrm{l}^{-1}$, respectively. Significantly lower values were determined for the carrot juices $(\mathrm{p}<0.05)$. The mean nitrite content for all juices was below $3.2 \mathrm{mg} \mathrm{l}^{-1}$.

[Insert Table 1 about here] 


\section{Nitrates, nitrites and pH value.}

Storage experiments were performed at ambient $\left(20-22{ }^{\circ} \mathrm{C}\right)$ and refrigerator $\left(4-6{ }^{\circ} \mathrm{C}\right)$ temperatures during 24 and 48 hours.

Series 1 . The changes in nitrate and nitrite mean contents in a small-scale company produced slightly pasteurized juices during open storage are shown in Table 2. Nitrate content decreased in all three juices during storage at both temperatures. The biggest decrease in nitrate content were found during 48 hours of storage for carrot, cabbage and beetroot juices at the ambient temperature, $47 \%$ (87 to $46 \mathrm{mg} \mathrm{l}^{-1}$ ), 39\% (250 to $152 \mathrm{mg} \mathrm{l}^{-1}$ ), 57\% (1708 to $739 \mathrm{mg} \mathrm{l}^{-1}$ ), respectively. After 48 hours of storage at refrigerated temperatures smaller decreases in nitrate contents was found, $11-30 \%$ in comparison with the initial contents. The biggest increase of nitrites, from 3.2 to $11.1 \mathrm{mg} \mathrm{l}^{-1}$ and from 3.2 to $6.8 \mathrm{mg} \mathrm{l}^{-1}$ was found for raw beetroot juice during storage both at ambient and refrigerated temperatures, respectively (Table 2). The pH dynamics of the juice samples is shown in Table 2. In the carrot juice, stored during $48 \mathrm{~h}$ at ambient temperatures, the highest $\mathrm{pH}$ decrease, from 6.3 to 4.1, was measured. The $\mathrm{pH}$ changes were lower in juices, stored at refrigerator temperatures.

[Insert Table 2 about here]

Series 2. The changes in nitrate and nitrite mean contents in the homemade carrot, cabbage, radish and pumpkin raw juices are shown in Figure 1. During the storage the nitrate contents in juices were decreasing and conversely, the nitrite contents were increasing. Changes in nitrate and nitrite contents depend on the juice type and storage conditions. Storage of the homemade raw juices for $24 \mathrm{~h}$ at ambient temperatures is clearly unacceptable, because the nitrite contents in carrot, beetroot and radish juices increases significantly $(p<0.05)$ (Figure 1 A, B, D). Also, there was statistically significant increase of nitrite content (Figure $1 \mathrm{E}$ ) in cabbage juices $(p<0.05)$. At the same time the nitrate contents decreased during 24 hour storage in the range of $26-66 \%$ of the initial contents. The biggest decrease in nitrate content was found after $24 \mathrm{~h}$ storage at ambient temperatures for carrot and beetroot juices, from 163 to $64 \mathrm{mg} \mathrm{l}^{-1}$ and from 2625 to $692 \mathrm{mg} \mathrm{l}^{-1}$, respectively (Table 4, Figure $1 \mathrm{~A}, \mathrm{~B}$ ). Nitrate contents decreased during $48 \mathrm{~h}$ of storage at ambient temperatures for carrot, beetroot and radish raw juices, from 163 to $6.7 \mathrm{mg} \mathrm{l}^{-1}, 2625$ to $523 \mathrm{mg} \mathrm{l}^{-1}$ and 4615 to $1772 \mathrm{mg} \mathrm{l}^{-1}$, respectively (Figure 1 A, B, D). At the same time, there was a considerable increase in nitrite content from 0.1 to $187 \mathrm{mg} \mathrm{l}^{-1}$, from 2.1 to $578 \mathrm{mg} \mathrm{l}^{-1}$ and from 0.5 to $259 \mathrm{mg} \mathrm{l}^{-1}$ was 
registered, respectively (Figure 1 A, B, D). For example, during 48 hours of storage of the cabbage juice at the ambient temperature the nitrate contents decreased from 116 to $44 \mathrm{mg} \mathrm{l}^{-1}$, at the same time the nitrite contents stayed below $2.3 \mathrm{mg}^{-1}$ (Figure $1 \mathrm{C}$ ). In general, during $48 \mathrm{~h}$ of storage at refrigerated temperatures the nitrate contents decreased. The biggest decreases, from 163 to $108 \mathrm{mg} \mathrm{l}^{-1}$ and from 2625 to 1486 were found for carrot and beetroot raw juices, respectively (Figure $1 \mathrm{~A}, \mathrm{~B}$ ). At the same time, during the $48 \mathrm{~h}$ storage at refrigerated temperatures, nitrite contents increased mostly for carrot juice, $47 \mathrm{mg}^{-1}$ and less for beetroot and radish juice, 4.9 and $11.2 \mathrm{mg}^{-1}$, respectively (Figure 1).

In an earlier study, Heisler et al. (1974) reported a considerable decrease in nitrate and increase of nitrite content during 24 hours at ambient temperature for the beetroot and spinach raw juices. The nitrite content of beetroot and spinach juices increased up to 540 and 900$1000 \mathrm{mg} \mathrm{kg}^{-1}$, respectively. The nitrate content decreased from 3800 to 2800 and from 1500 to $350 \mathrm{mg} \mathrm{kg}^{-1}$, respectively (Heisler et al. 1974).

The $\mathrm{pH}$ dynamics of the raw juice samples is illustrated in Figure 1. The $\mathrm{pH}$ of the juices did not change considerably during the storage at refrigerated temperatures. Differently, at ambient temperatures, the highest decrease of $\mathrm{pH}$ value from initial 6.4 to 4.2 was observed in radish juice. The $\mathrm{pH}$ of the raw juice samples was measured at 0,24 and $48 \mathrm{~h}$ of storage. Generally, during the storage studies, the $\mathrm{pH}$ decreased and nitrite contents and total viable counts increased (Figure 1). Since both nitrite concentration and total viable microbial counts increased during storage it may be concluded that microbial activity was the main factor in nitrate reduction process. Better correlations between the nitrite content and total viable counts were found in vegetable juices after storage at ambient temperatures ( $r=0.9$ to 0.58$)$ It can be explained by microbiological reduction of nitrite from nitrate ion. The negative correlations between nitrate content and total viable counts were found from homemade carrot juice and homemade radish juice $(\mathrm{r}=-0.84$ to -0.81$)$.

It is recommended to use only fresh-prepared homemade carrot juices for babies. Raw material used for the preparation of juices should have as low initial nitrate content as possible.

\section{[Insert Figure 1 about here]}

Figure 1. The changes of nitrate and nitrite content during storage in raw homemade vegetables juices - carrot juice $A$, beetroot juice $B$, cabbage juice $C$, radish juice $\mathrm{D}$, pumpkin juice $\mathrm{E}$ 


\section{Microbiological count and $\mathrm{pH}$ value.}

All the products were analyzed for total viable bacterial, coliform bacteria, yeasts and moulds counts. In the series 1 , three different vegetable-based small-scale industry produced raw juices and in series 2, five different homemade vegetable-based raw juices were microbiologically analyzed. During the storage, all the species of the microorganisms showed the increase in counts (Table 3 and Figure 1), while $\mathrm{pH}$ showed decrease tendency (Table 2 and Figure 1). Between the $\mathrm{pH}$ and total viable counts (log $\mathrm{cfu} / \mathrm{ml})$ clear negative correlations were determined $(\mathrm{r}=-0.95$ to $-0.75, \mathrm{p}<0.05)$. The decrease of $\mathrm{pH}$ is caused by the microorganisms' vital activity products, as indicated by the increase of microorganism multiplicity. As reported by Akin et al. (2008), pH decrease was assumed to correlate with the nitrogen consumption of the studied microorganism strains. The nitrogen concentration did not influence the $\mathrm{pH}$ itself but during the fermentation, the consumption of nitrogen by yeasts produces $\mathrm{H}^{+}$ions (Castrillo et al. 1995). In Table 3 it is shown that compared to initial microorganism counts, after 48 hours of storage at ambient temperature the average percentage in counts of microorganisms in homemade raw juices were higher than for commercially produced juices, 173 and $161 \%$, respectively. During the storage experiment of the industrial lightly pasteurized raw juices at ambient temperatures for $48 \mathrm{~h}$ the bacterial total counts increased from 5.03-5.33 log cfu/ml to 7.81-8.85 $\log \mathrm{cfu} / \mathrm{ml}$. During the storage of the homemade juices at ambient temperature for $48 \mathrm{~h}$ the total bacterial counts increased from 5.14-5.39 $\log \mathrm{cfu} / \mathrm{ml}$ to $8.84-9.19 \log \mathrm{cfu} / \mathrm{ml}$, with the average increase $3.8 \mathrm{log} \mathrm{cfu} / \mathrm{ml}$.

During storage of raw juices at ambient temperatures, the total counts of coliform bacteria and moulds and yeast increased significantly $(\mathrm{p}<0.05)$. Higher increase of microorganism counts was detected in the homemade juices.

[Insert Table 3 about here]

\section{Intake calculation of nitrate and nitrite}

Adults. The intake of nitrate and nitrite has been calculated in accordance with the recommendations given by Estonian and other dietitians (Heinerman, 1994, Yabsley and Gross, 2001, Kroom, 2008). The recommended consumption data of the homemade vegetable based raw juices and calculated ADI percentages are shown in Table 4. In calculations of nitrate and nitrite daily intakes, $65 \mathrm{~kg}$ was used as the average body weight of Estonian adults. 
The average consumption amounts of vegetable raw juices in accordance with dietitians' recommendations were 100 to $300 \mathrm{ml}$ dependent on the juice variety. The daily doses of nitrate and nitrite depend on initial contents of $\mathrm{NO}_{3}{ }^{-}$and $\mathrm{NO}_{2}{ }^{-}$in vegetable based raw juices (Table 4). Additionally, it depends on consumption amounts and storage conditions of the vegetable-based raw juices. The daily doses are exceeded by adults even by consumption of freshly made beetroot and radish juices as well as by using the same juices after $24 \mathrm{~h}$ of storage at refrigerated temperatures, $164 \%, 193 \%$ and 109\%, 172\% of ADI, respectively (Table 4). Daily doses of nitrites when juices are stored at same conditions are generally low and in range of $0.8 \%$ to $16 \%$ of ADI, exceptional was a carrot juice with $30 \%$ of ADI. Nitrite daily doses increased significantly $(\mathrm{p}<0.05)$ when the juices were stored at ambient temperatures for $24 \mathrm{~h}$, at the same time the nitrate doses decreased. Nitrite doses in the case of consumption of $300 \mathrm{ml}$ raw carrot juice, $150 \mathrm{ml}$ raw beetroot juice and $100 \mathrm{ml}$ of raw radish juice exceeded ADI values 846\%, 346\% and 167\%, respectively. Beetroot and radish juices could be mixed with other vegetable based raw juices as recommended by dietitians (Heinerman, 1994; Kroom, 2008). Industrially produced raw juices are lightly pasteurized and therefore the nitrate and nitrite changes (Table 2) are lower compared to the homemade juices (Table 4). Consequently, the nitrate and nitrite daily doses are also considerably lower and will not exceed the ADI values.

[Insert Table 4 about here]

Infants and young children. According to our data obtained from questionnaires, filled in by parents, the most popular raw vegetable juices given to young children were carrot based raw juices. Generally, carrot juices contain nitrates in low concentrations. In our study the carrot raw juices produced by Estonian small-scale industry and in homemade juices contained nitrates 87 and $163 \mathrm{mg} \mathrm{l}^{-1}$, respectively (Table 2 and 4).

Recommended consumption of raw carrot juices and related nitrates and nitrites daily doses are shown in Table 5. In accordance with our data, it is obvious that only freshly made carrot raw juices can be used for infants because the ADI values of nitrate and nitrite were $12.9 \%$ and $0.5 \%$, respectively. Consumption of the fresh and $24 \mathrm{~h}$ at refrigerated temperatures stored homemade carrot raw juices increased nitrite daily intakes to $19.7 \%$ of ADI. During $24 \mathrm{~h}$ of storage at ambient temperatures of the homemade carrot raw juices the nitrite contents were higher compare to storage in refrigerator which resulted with the mean values of $110 \mathrm{mg}^{-1}$ 
(Table 4). Consumption of a juice containing $110 \mathrm{mg}^{-1}$ of nitrite by 10-12 months-old infants $30 \mathrm{ml}$ as the maximum amount recommended by dieticians and $50 \mathrm{ml}$ for 1-2 years old young children could be harmful for health because the mean nitrite intake is $540 \%$ and $733 \%$ of ADI, respectively (Table 5). According to the calculations by Phillips (1968), one dose of raw vegetable juice in amount of $30 \mathrm{ml}$ could result in cyanosis for a 1-year-old child.

Lightly pasteurized carrot raw juice (Table 2) made in small-scale industry could be given for young child even after $24 \mathrm{~h}$ of storage at refrigerated temperatures because as shown in Table 2 the nitrate and nitrite contents had only minor changes, $87 \mathrm{mg} \mathrm{l}^{-1}$ to $80 \mathrm{mg} \mathrm{l}^{-1}$ and 0.1 $\mathrm{mg} \mathrm{l}^{-1}$ to $0.2 \mathrm{mg} \mathrm{l}^{-1}$, respectively. In the present case the mean daily nitrate dose for infants in result of consumption of carrot raw juices will stay below $10 \%$ of ADI and nitrite dose will not exceed $2 \%$ of ADI.

[Insert Table 5 about here]

\section{Conclusions}

The initial contents and changes in the dynamics of nitrates and nitrites were determined after 24 and 48 hours of storage at ambient and refrigerated temperatures of homemade (carrot, beetroot, cabbage, radish, pumpkin) and commercially produced raw vegetable based juices (carrot, beetroot, cabbage). A significant decrease $(\mathrm{p}<0.05)$ in nitrate and a significant increase $(\mathrm{p}<0.05)$ in nitrite contents in homemade carrot, beetroot and radish raw juices after 48 hours of storage at ambient temperatures was found. Nitrite contents of carrot, beetroot and radish raw juices were high already after $24 \mathrm{~h}$ of storage at ambient temperatures. Therefore, the consumption of the homemade vegetable based raw juices is recommended only shortly after preparation. The industrially produced lightly pasteurized raw juices can be openly stored at refrigerated temperatures for a maximum of 24 hours. In conclusion, very high nitrite intakes from vegetable based raw juices can occur when juices are stored for a long time at an improper e.g. at ambient temperatures. Acceptable daily intakes can be exceeded 5-8 fold for young children and 2-8 fold for the adults.

\section{References}

Akin H, Brandam C, Meyer X-M, Strehaiano P. 2008. A model for $\mathrm{pH}$ determination during alcoholic fermentation of a grape must by Saccharomyces cerevisiae. Chem. Eng. Process. 47(11):1986-1993. 
Belitz H-D, Grosch W, Schieberle P. 2004. Food Chemistry. $3^{\text {rd }}$ revised Edition ed. Berlin Heidelberg: Springer. Chapter: Food Additives; p. 460-461, 501.

Castrillo JI, De Miguel I, Ugalde UO. 1995. Proton production and consumption pathways in yeast metabolism. A chemostat culture analysis, Yeast 11:1353-1365

Chung JC, Chou SS, Hwang DF. 2004. Changes in nitrate and nitrite content of four vegetables during storage at refrigerated and ambient temperatures. Food Addit. Contam. 21(4):317-322.

Chung SY, Kim JS, Kim M, Hong MK, Lee JO, Kim CM, Song IS. 2003. Survey of nitrate and nitrite contents of vegetables grown in Korea. Food Addit. Contam. 20(7):621-628.

Coss A, Cantor KP, Reif JS, Lynch FC, Ward, MH. 2003. Pancreatic cancer and drinking water and dietary sources of nitrate and nitrite. Am. J. Epidemiol. 159(7):693-701.

EFSA - European Food Safety Authority. 2008. Nitrate in vegetables Scientific Opinion of the Panel on Contaminants in the Food Chain. The EFSA Journal 689:1-79.

Ellen G, Egmond E, Van Loon JW, Sahertian ET, Tolsma K. 1990. Dietary intakes of some essential and non-essential trace elements, nitrate, nitrite and $\mathrm{N}$-nitrosamines, by Dutch adults: estimated via a 24-hour duplicate portion study. Food Addit Contam. 7(2):207-21.

Ezeagu EI. 1996. Nitrate and nitrite contents in ogi and the changes occurring during storage. Food Chem. 56(1):77-79.

EVS-EN ISO 4833:2006 Microbiology of food and animal feeding stuffs - Horizontal method for the enumeration of microorganisms - Colony-count technique at 30 degrees $\mathrm{C}$.

EVS-EN ISO 6887-1:2001 Microbiology of food and animal feeding stuffs. Preparation of test samples, initial suspension and decimal dilutions for microbiological examination. Part 1: General rules for the preparation of the initial suspension and of decimal dilutions.

EVS-EN 1132:2000 Fruit and vegetable juices. Determination of the pH-value.

EVS-ISO 7954:1999 Microbiology. General guidance for enumeration of yeasts and moulds. Colony count technique at $25^{\circ} \mathrm{C}$.

Hsu J, Arcot J, Lee NA. 2009. Nitrate and nitrite quantification from cured meat and vegetables an their estimated dietary intake in Australians. Food Chem. 115(1):334-339.

Heinerman J. 1994. Heinerman`s encyclopedia of juice cures. Reward Books.

Heisler EG, Siciliano J, Krulick S, Feinberg J, Schwartz H. 1974. Changes in Nitrate and Nitrite Content, and Search for Nitrosamines in Storage-Abused Spinach and Beets. J. Agric.Food Chem. 22(6):1029-1032.

Hill MJ. 1996. Nitrates and nitrites from food and water in relation to human disease. $2^{\text {nd }}$ ed, Woodhead Publishing Ltd, Cambridge. 
JECFA 2002. (Joint FAO/WHO Expert Committee on Food Additives); [cited 2009 May 10]. http://www.inchem.org/documents/jecfa/jecmono/v50je06.htm

Kolb E, Haug M. 1997. Potential Nitrosamine Formation and its Prevention During Biological Denitrification of Red Beet Juice. - Food Chem. Toxic. 35:219-224.

Kroes R, Müller D, Lambe J, Löwik MRH, van Klaveren J, Kleiner J, Massey R, Mayer S, Urieta I, Verger P, Visconti A. 2002. Assessment of intake from the diet. Food Chemic. Toxic. 40:327-385.

Kroom G. 2008. Porgandi raviomadused. Odamees; p. 1-95

Li H, Meininger CJ, Wu G. 2000. Rapid determination of nitrite by reversed-phase highperformance liquid chromatography with fluorescence detection. J. Chromatogr. B. 746:199207.

Misko TP, Schilling RJ, Salvemini D, Moore WM, Currie MG. 1993. A Fluorometric Assay for the Measurment of Nitrite in Biological Samples. Anal. Biochem. 214:11-16.

Meah MN, Harrison N, Davies A. 1994. Nitrate and nitrite in foods and the diet. Food Addit. Contam. 11(4):519-32.

Mensinga TT, Speijers GJA, Meulenbelt J. 2003. Health implications of exposure to environmental nitrogenous compounds, Toxicol. Rev. 22(1):41-51.

Murata M, Kishida N, Ishinaga M. 2002. Survey of the daily intake of nitrate and nitrite in school children by the duplicate portion method. Shokuhin Eiseigaku Zasshi. 43(2):57-61.

Nabrzyski M, Gajewska R. 1994. The content of nitrates and nitrites in fruits, vegetables and other foodstuffs. Roczniki PZH. 45(3):167-180.

NMKL 44 5th edition 2001. Food and fodder. Determination of coliform bacteria.

Pennington JAT. 1998 Dietary exposure models for nitrates and nitrites. Food Control. 9(6):385-395.

Penttilä PL, Räsänen L, Kimppa S. 1990. Nitrate, nitrite, and N-nitroso compounds in Finnish foods and the estimation of the dietary intakes. Z Lebensm Unters Forsch. (4):336-40.

Phillips WEJ. 1968. Changes in the Nitrate and Nitrite Contents of Fresh and Processed Spinach during Storage. J. Agric. Food Chem. 16(1):88-91.

Sadler, G.D., Parish, M.E., Wicker, L. (1992) Microbial, enzymatic, and chemical changes during storage of fresh and processed orange juice. Journal of Food Science, 57, 1187-1191.

Sanchez-Echaniz J, Benito-Fernández J, Mintegui-Raso S. 2001. Methemoglobinemia and Consumption of Vegetables in Infants. - Pediatrics. 5(107):1024-1028.

Santamaria P. 2006. Nitrate in vegetables: toxicity, content, intake and EC regulation. J. Sci. Food Agric. 86:10-17 
Tamme T, Reinik M, Roasto M, Juhkam K Tenno T, Kiis A. 2006. Nitrates and nitrites in vegetables and vegetable-based products and their intakes by the Estonian population, Food Addit. Contam. 23(4):355-361.

Thomson BM, Nokes CJ, Cressey PJ. 2007. Intake and risk assessment of nitrate and nitrite from New Zealand foods and drinking water. Food Addit. Contam. 24(2):113-121.

Yabsley C, Cross A. 2001. Miracle Juices. Octopus Publishing Group Ltd.

Walker R. 1990. Nitrates, nitrites and N-nitroso compounds: a Rewiew of the occurance in food and diet and the toxicological implications. Food Addit. Contam. 7:717-768.

WHO 1995. Evaluation of certain food additives and contaminants. Joint FAO/WHO Expert Committee on Food Additives. WHO Techn. Rep. 859:29-35.

WHO 2006. GEMS/Food Consumption Cluster Diets; [cited 2009 May 10]. Available at http://www.who.int/foodsafety/chem/gems/en/index1.html 
The changes of nitrate and nitrite content during storage in raw homemade vegetables juices carrot juice $A$, beetroot juice $B$, cabbage juice $C$, radish juice $D$, pumpkin juice $E$ 
Table 1. Nitrate and nitrite initial contents of raw vegetable juices, 5 replications

\begin{tabular}{lllll}
\hline Vegetable juice & \multicolumn{2}{c}{ Nitrate $\mathrm{mg} \mathrm{l}^{-1}$} & \multicolumn{2}{c}{ Nitrite $\mathrm{mg}^{-1}$} \\
\cline { 2 - 5 } & Range & Mean & Range & Mean \\
\hline Commercial juices & $47-139$ & 87 & LOQ-0.4 & 0.1 \\
Carrot juice & $1097-2257$ & 1707 & $0.23-10.2$ & 3.2 \\
Red beetroot juice & $171-415$ & 250 & LOQ-2.7 & 0.6 \\
Cabbage juice & & & & \\
Homemade juices & $40-311$ & 163 & LOQ-0.2 & 0.1 \\
Carrot juice & $130-6479$ & 2625 & LOQ-4.2 & 2.1 \\
Red beetroot juice & $38-299$ & 116 & LOQ-0.9 & 0.23 \\
Cabbage juice & $3714-6553$ & 4615 & $0.23-0.9$ & 0.5 \\
Radish juice & $148-520$ & 255 & LOQ-1.4 & 1.0 \\
Pumpkin juice & & & & \\
\hline
\end{tabular}

LOQ - limit of quantification

$\mathrm{NO}_{3}^{-}$: LOQ $0.23 \mathrm{mg} \mathrm{l}^{-1}$

$\mathrm{NO}_{2}^{-}:$LOQ $0.10 \mathrm{mg} \mathrm{l}^{-1}$ 
Table 2. The changes of mean nitrate and nitrite content during storage of commercial raw vegetable juice $(5$ replications $)$ at ambient $\left(20-22^{\circ} \mathrm{C}\right)$ and refrigerated $\left(4-6^{\circ} \mathrm{C}\right)$ temperature

\begin{tabular}{lllllllc}
\hline $\begin{array}{l}\text { Type of } \\
\text { juice }\end{array}$ & $\begin{array}{l}\text { Storage } \\
\text { period } \\
\text { (hours) }\end{array}$ & \multicolumn{2}{c}{ Nitrate $\mathrm{mg} \mathrm{l}^{-1}$} & \multicolumn{3}{c}{ Nitrite $\mathrm{mg} \mathrm{l}^{-1}$} & \multicolumn{2}{c}{$\mathrm{pH}$} \\
\cline { 2 - 7 } & $20-22^{\circ} \mathrm{C}$ & $4-6^{\circ} \mathrm{C}$ & $20-22^{\circ} \mathrm{C}$ & $4-6^{\circ} \mathrm{C}$ & $20-22^{\circ} \mathrm{C}$ & $4-6^{\circ} \mathrm{C}$ \\
\hline Carrot & 0 & 87 & 87 & 0.1 & 0.1 & 6.3 & 6.3 \\
juice & 24 & 63 & 80 & 0.4 & 0.2 & 5.3 & 6.3 \\
& 48 & 46 & 62 & 2.7 & 1.5 & 4.1 & 6.2 \\
& & & & & & & \\
Cabbage & 0 & 250 & 250 & 0.6 & 0.6 & 6.0 & 6.0 \\
juice & 24 & 192 & 236 & 1.3 & 0.6 & 5.0 & 5.7 \\
& 48 & 152 & 188 & 1.5 & 1.2 & 4.2 & 5.5 \\
& & & & & & & \\
Red & 0 & 1708 & 1708 & 3.2 & 3.2 & 5.9 & 5.9 \\
beetroot & 24 & 1158 & 1606 & 7.1 & 4.7 & 5.0 & 5.8 \\
juice & 48 & 739 & 1517 & 11.1 & 6.8 & 4.2 & 5.7 \\
\hline
\end{tabular}


Table 3. Effect of ambient $\left(20-22^{\circ} \mathrm{C}\right)$ and refrigerated $\left(4-6{ }^{\circ} \mathrm{C}\right)$ storage conditions to raw vegetables juices (5 replications) microbiological counts

\begin{tabular}{|c|c|c|c|c|c|c|c|}
\hline \multirow[t]{3}{*}{$\begin{array}{l}\text { Type of } \\
\text { juice }\end{array}$} & \multirow[t]{3}{*}{$\begin{array}{l}\text { Storage } \\
\text { time }\end{array}$} & \multicolumn{2}{|c|}{$\begin{array}{l}\text { Total microbial } \\
\text { count } \log \mathrm{cfu} / \mathrm{ml}^{*}\end{array}$} & \multicolumn{2}{|c|}{$\begin{array}{l}\text { Coliforms log } \\
\mathrm{cfu} / \mathrm{ml}^{*}\end{array}$} & \multicolumn{2}{|c|}{$\begin{array}{l}\text { Molds and Yeast log } \\
\mathrm{cfu} / \mathrm{ml}^{*}\end{array}$} \\
\hline & & $20-22^{\circ} \mathrm{C}$ & $4-6^{\circ} \mathrm{C}$ & $20-22^{\circ} \mathrm{C}$ & $4-6^{\circ} \mathrm{C}$ & $20-22^{\circ} \mathrm{C}$ & $4-6^{\circ} \mathrm{C}$ \\
\hline & & $\mathrm{I}^{\mathrm{a}} / \mathrm{H}^{\mathrm{b}}$ & $\mathrm{I}^{\mathrm{a}} / \mathrm{H}^{\mathrm{b}}$ & $\mathrm{I}^{\mathrm{a}} / \mathrm{H}^{\mathrm{b}}$ & $\mathrm{I}^{\mathrm{a}} / \mathrm{H}^{\mathrm{b}}$ & $\mathrm{I}^{\mathrm{a}} / \mathrm{H}^{\mathrm{b}}$ & $\mathrm{I}^{\mathrm{a}} / \mathrm{H}^{\mathrm{b}}$ \\
\hline \multirow[t]{3}{*}{ Carrot juice } & 0 & $5.13 / 5.17$ & $5.13 / 5.17$ & $2.97 / 4.43$ & $2.97 / 4.43$ & $4.18 / 3.76$ & $4.18 / 3.76$ \\
\hline & $24 \mathrm{~h}$ & $6.56 / 7.13$ & $5.65 / 5.44$ & $4.94 / 6.15$ & $4.03 / 4.63$ & $5.01 / 4.37$ & 4.78/4.01 \\
\hline & $48 \mathrm{~h}$ & $8.85 / 8.84$ & $6.73 / 7.33$ & $5.64 / 6.95$ & $4.96 / 5.83$ & $5.9 / 5.73$ & $4.97 / 4.73$ \\
\hline Cabbage & 0 & $5.33 / 5.14$ & $5.33 / 5.14$ & $4.69 / 4.54$ & $4.69 / 4.54$ & $4.11 / 3.58$ & $4.11 / 3.58$ \\
\hline \multirow[t]{2}{*}{ juice } & $24 \mathrm{~h}$ & $7.24 / 7.50$ & $5.88 / 5.38$ & $5.97 / 5.09$ & $4.78 / 4.91$ & $5.25 / 3.8$ & $4.29 / 3.07$ \\
\hline & $48 \mathrm{~h}$ & $8.29 / 9.19$ & $6.37 / 6.59$ & $6.59 / 5.82$ & $5.53 / 5.24$ & $6.46 / 4.2$ & $4.77 / 3.82$ \\
\hline Red & 0 & $5.03 / 5.39$ & $5.03 / 5.39$ & $3.38 / 3.85$ & $3.38 / 3.85$ & $2.94 / 2.74$ & $2.94 / 2.74$ \\
\hline beetroot & $24 \mathrm{~h}$ & $6.88 / 7.55$ & $5.39 / 5.72$ & $5.57 / 6.07$ & $4.69 / 4.34$ & $3.61 / 3.98$ & $2.89 / 3.30$ \\
\hline juice & $48 \mathrm{~h}$ & $7.81 / 9.03$ & $6.77 / 6.74$ & $6.14 / 6.70$ & $5.59 / 5.07$ & $4.53 / 4.65$ & $3.57 / 3.73$ \\
\hline
\end{tabular}


Table 4. The mean content of nitrate and nitrite and changes during storage in raw homemade vegetable juices and daily intake by Estonian adults

\begin{tabular}{|c|c|c|c|c|c|c|c|}
\hline $\begin{array}{l}\text { Vegetable } \\
\text { juice }\end{array}$ & $\begin{array}{l}\text { Nitrate } \\
\text { content } \\
\mathrm{mg} \mathrm{l}^{-1}\end{array}$ & $\begin{array}{l}\text { Nitrite } \\
\text { content } \\
\mathrm{mg} \mathrm{l}^{-1}\end{array}$ & $\begin{array}{l}\text { Recommended } \\
\text { mean intake of } \\
\text { juice per day, } \mathrm{ml} *\end{array}$ & $\begin{array}{l}\text { Expected } \\
\text { nitrate intake } \\
\text { mg day }^{-1} \\
\end{array}$ & $\begin{array}{l}\% \text { of } \\
\text { ADI }\end{array}$ & $\begin{array}{l}\text { Expected } \\
\text { nitrite intake } \\
\text { mg day }^{-1}\end{array}$ & $\begin{array}{l}\% \text { of } \\
\text { ADI }\end{array}$ \\
\hline \multicolumn{8}{|c|}{ Raw juices before storage } \\
\hline Carrot & 163 & 0.1 & 300 & 49.0 & 20.4 & 0.03 & 0.8 \\
\hline Cabbage & 116 & 0.23 & 200 & 23.0 & 9.7 & 0.05 & 1.2 \\
\hline $\begin{array}{l}\text { Red } \\
\text { beetroot }\end{array}$ & 2625 & 2.1 & 150 & 394.0 & 164.0 & 0.32 & 8 \\
\hline Radish & 4615 & 0.5 & 100 & 462.0 & 193.0 & 0.05 & 1.3 \\
\hline Pumpkin & 255 & 1.0 & 200 & 51.0 & 21.3 & 0.2 & 5.1 \\
\hline \multicolumn{8}{|c|}{ Raw juices after storage at refrigeration temperature $\left(4-6^{\circ} \mathrm{C}\right)$ within $24 \mathrm{~h}$} \\
\hline Carrot & 152 & 3.9 & 300 & 45.6 & 19.0 & 1.17 & 30 \\
\hline Cabbage & 100 & 0.4 & 200 & 20.0 & 8.3 & 0.08 & 2.1 \\
\hline $\begin{array}{l}\text { Red } \\
\text { beetroot }\end{array}$ & 1745 & 2.5 & 150 & 262.0 & 109.0 & 0.38 & 9.6 \\
\hline Radish & 4126 & 1.5 & 100 & 413.0 & 172.0 & 0.15 & 3.8 \\
\hline Pumpkin & 230 & 3.1 & 200 & 46.0 & 19.2 & 0.62 & 16 \\
\hline \multicolumn{8}{|c|}{ Raw juices storage at ambient temperature $\left(20-22^{\circ} \mathrm{C}\right)$ within $24 \mathrm{~h}$} \\
\hline Carrot & 64 & 110.0 & 300 & 19.0 & 8.0 & 33.0 & 846 \\
\hline Cabbage & 65 & 1.2 & 200 & 13.0 & 5.4 & 0.24 & 6.2 \\
\hline $\begin{array}{l}\text { Red } \\
\text { beetroot }\end{array}$ & 692 & 90.0 & 150 & 103.8 & 43.3 & 13.4 & 346 \\
\hline Radish & 2633 & 65.1 & 100 & 263.0 & 109.7 & 6.5 & 167 \\
\hline Pumpkin & 167 & 14.3 & 200 & 33.4 & 13.9 & 2.86 & 73 \\
\hline
\end{tabular}

* calculated by the basis of the recommended by dietitians. 
Table 5. Estimated mean nitrate and nitrite intake by infants and young children after consumption of raw home-made carrot juice

\begin{tabular}{|c|c|c|c|c|c|c|}
\hline $\begin{array}{l}\text { Storage } \\
\text { condition }\end{array}$ & $\begin{array}{l}\mathrm{NO}_{3}^{-} \\
\text {content } \\
\mathrm{mg} \mathrm{l}^{-1} \\
\end{array}$ & $\begin{array}{l}\mathrm{NO}_{2}^{-} \\
\text {content } \\
\mathrm{mg} \mathrm{l}^{-1}\end{array}$ & $\begin{array}{l}\text { Mean } \mathrm{NO}_{3}{ }^{-} \\
\text {intake mg } \\
\text { per day }\end{array}$ & $\%$ of ADI & $\begin{array}{l}\text { Mean } \mathrm{NO}_{2}^{-} \\
\text {intake mg per } \\
\text { day }\end{array}$ & $\%$ of $\mathrm{ADI}$ \\
\hline $\begin{array}{l}\text { Fresh raw } \\
\text { juice }\end{array}$ & 163 & 0.1 & $\begin{array}{l}4.9^{\mathrm{a}} \\
8.2^{\mathrm{b}}\end{array}$ & $\begin{array}{l}12.9^{\mathrm{a}} \\
17.8^{\mathrm{b}}\end{array}$ & $\begin{array}{l}0.003^{\mathrm{a}} \\
0.005^{\mathrm{b}}\end{array}$ & $\begin{array}{l}0.5^{\mathrm{a}} \\
0.7^{\mathrm{b}}\end{array}$ \\
\hline $\begin{array}{l}\text { Stored } 24 \mathrm{~h} \\
\text { at } 4-6^{\circ} \mathrm{C}\end{array}$ & 152 & 3.9 & $\begin{array}{l}4.6^{\mathrm{a}} \\
7.6^{\mathrm{b}}\end{array}$ & $\begin{array}{l}12.0^{\mathrm{a}} \\
16.5^{\mathrm{b}}\end{array}$ & $\begin{array}{l}0.12^{\mathrm{a}} \\
0.20^{\mathrm{b}}\end{array}$ & $\begin{array}{l}19.7^{\mathrm{a}} \\
26.6^{\mathrm{b}}\end{array}$ \\
\hline $\begin{array}{l}\text { Stored } 24 \mathrm{~h} \\
\text { at } 20-22^{\circ} \mathrm{C}\end{array}$ & 64 & 110 & $\begin{array}{l}1.9^{\mathrm{a}} \\
3.2^{\mathrm{b}}\end{array}$ & $\begin{array}{l}5.0^{\mathrm{a}} \\
7.0^{\mathrm{b}}\end{array}$ & $\begin{array}{l}3.3^{\mathrm{a}} \\
5.5^{\mathrm{b}}\end{array}$ & $\begin{array}{l}540^{\mathrm{a}} \\
733^{\mathrm{b}}\end{array}$ \\
\hline
\end{tabular}

${ }^{\mathrm{a}} 10$ - 12 months infants, mean body weight $10.2 \mathrm{~kg}$ - recommended consumption of raw carrot juice $30 \mathrm{ml}$ per day

b 1 - 2 year young children, mean body weight $12.5 \mathrm{~kg}$ - recommended consumption of raw carrot juice $50 \mathrm{ml}$ per day 